\title{
An Investigation of the Writing Test Used at the Institute of International Studies, Ramkhamhaeng University (IIS-RU), Thailand
}

\section{VENUS KANSOPON}

Bangkok, Thailand

\begin{abstract}
Bio Data:
Venus Kansopon earned an Associate of Arts (AA) degree from Wilbur Wright College in Chicago and obtained her Bachelor of Arts in English from Institute of International Studies, Ramkhamhaeng University. She is now pursuing Master of Teaching English as an International Language program (MTEIL) at Shinawatra International University.
\end{abstract}

\begin{abstract}
This study primarily investigated the validity and reliability of the writing assessments and their backwash effects on the undergraduates of Institute of International Studies, Ramkhamhaeng University (IISRU). The English-major students had academic writing skills problem, especially among the non-native English speakers, whose writing ability was critical to their academic achievement as they were required to produce many academic writing tasks. There were some native English speaking students who were also unable to write essays or compose properly. The IIS professors motivated their students to develop their writing skills by using writing tests (e.g., essay exam and writing prompt test) as the instruments to measure students' writing competence, ability, and knowledge in curriculum.
\end{abstract}

\section{Introduction}

Writing competence predicts student's academic achievement. Writing is a key element of communication and a critical part of comprehension. The ability to write clearly is an essential skill needed by undergraduate and graduate students. Writing proficiency, in particular, is being addressed as a skill that is integral to effective communication. Although multiple-choice tests provide some indicators of written language skill, they do so indirectly (Carson, Bridgeman, Camp and Waanders, 1985). Furthermore, writing is a suitable way to test a student's ability in the final exam because it can show an ability to understand structure as well as content. Structure is very important in writing and is therefore overlooked if essay skills are not examined during a course. It also does not allow cheating as much as in written/multiple choice tests. Importantly, writing is a very valid skill to test student's skills in many areas. As mentioned, multiple choice tests allow for a higher 
level of cheating or guessing and do not test the student's ability to compose a written piece or to structure it. Multiple choice tests also suggest 'right' and 'wrong' answers and take away from the basic art of writing as something very subjective and individual (Finch, 2012). In addition, essay items, for example, are an effective way to measure higher level cognitive objectives. They are unique in measuring students' ability to select content, organize and integrate it, and present it in logical prose. Essay exams have a good effect on students' learning because they do not memorize facts but try to get a broad understanding of complex ideas to see relationships. Essay exams present a more realistic task to the student. In real life, questions will not be presented in a multiple-choice format but will require students to organize and communicate their thoughts (Jacobs, 2010).

With the recognition that many English-major students passed through the courses of English literature with minimal English language proficiency, the IIS professors were reevaluating their methods of teaching and testing and redefining their objectives. They finally came up with a new paradigm for writing assessment functionally based on communicative competencies and the development of an idea that flows. To achieve the most appropriate assessment of writing skills, their essay exam was designed to test not only knowledge but also the ability to organize and present thoughts under pressure of time limits. At the same time, students were motivated and enhanced their writing skills by a number of written assignments, essay exams, and writing prompt tests. Chiefly, the essay exam was frequently and effectively used as a major instrument to measure students' writing competence, skills, and knowledge in curriculum for their midterms and finals.

The purpose of this study was to investigate validity and reliability of the writing assessments and their backwash effects on the undergraduates at the Institute of International Studies, RU. The students are both native and non-native English speakers pursuing a degree of Bachelor of Arts in English. The study focused on the qualities of the writing assessments used to assess students' writing skills, knowledge, and ability. Importantly, the essay scrutinized the choices the IIS instructors made in assessment instruments in order to motivate students and focus their sense of academic achievement. This research study was to look into:

1. The improvement of student's writing ability and knowledge in curriculum resulted from taking a number of essay exams and writing prompt tests.

2. Essay exam and writing prompt test used as the valid and reliable instruments of measurement of students' writing competence, knowledge in curriculum, and ability.

3. The writing tests' backwash effects on teaching and learning approaches, e.g., teaching and learning outcomes, needs analysis and syllabus design.

\section{Methodology}

The qualitative method applied in this research essay was to obtain insights into the attitudes and values gained by the English-major undergraduates and their lecturers, which was caused by the backwash effects of writing tests at the IIS. The data used for this study were obtained by sampling in interviewing the target population, comprising of students and lecturers. Sample size is 44 . Four lecturers out of nine were interviewed, and eight students out of thirty-five were chosen. 
Expectedly, the results from this research study unfolded some teaching, testing and learning strategies and the development of writing assessments for educators, not only among the English-major students and their lecturers, but also among other international programs. The study highlighted the relationship between teaching, testing and learning. Hopefully, this study provided useful information for both professors and students and also increased the awareness of decision making on the instrument of assessment that must be valid and reliable. This research helps to meet the needs and concerns of, particularly, the non-native English speaking students studying in international education program.

\section{Data Collection}

Data was collected from interviews of professors and students at the IIS. Four professors out of nine and eight students out of thirty-five were chosen for these interviews. Survey questions were: (a) Do you think the written tests (e.g., essay exam and writing prompt test) improve students' writing ability? Why? (b) Is essay exam a valid and reliable tool of measurement? Why? and (c) Does the written test yield the backwash effects on teaching and learning approaches? How? The following responses are some examples from the interviews.

\section{Literature Review}

Gupta and Woldemariam (2011) described that in Ethiopia where English was used as a medium of instruction in both secondary and tertiary education. They found that students at the tertiary level encountered problems with their writing ability which was very critical to their academic success. The students were helped to develop the necessary writing skills by engaging them in a " 48 hour English writing course," covering 16 weeks of instruction at the Jimma University during their first year or second year program. From this extra English writing course, the students were able to compose their thoughts and ideas more clearly and logically and also were able to engage language more effectively. Students had difficulties in expressing themselves when they had less than 36 hours and were less motivated to perform writing tasks in and outside the classroom. The implication here is that the more students are motivated toward testing writing, which results in a higher use of the writing strategies will in turn lead to the development of a writing competence.

\section{Background of the IIS-RU}

Ramkhamhaeng University (RU) is the first Open University in Thailand established in 1971. The Institute of International Studies (IIS) is the result of RU's expansion into an international level by providing programs for BA, MA, and Ph.D. The IIS lecturers are native English speakers from the West and Oceania. The majority of students are Thais but also there are other Asians, and some of the minority is from different parts of the world.

The IIS English-major undergraduates had academic writing skills problem, especially among the non-native English speakers, whose writing ability was critical to their academic success as they were required to produce many academic writing tasks. There were some native English speaking students were also unable to write essays or compose properly. 
About the international program of Bachelor of Arts in English at the IIS, the curriculum consists of several literature courses as requirements such as Masterpieces of World Literature, William Shakespeare's Poems/Comedies, Social Criticism in Literature, Victorian and Edwardian Literature, American Best Sellers and Contemporary Fiction. Each course generally requires students to take essay exams for their midterm and final. The essay exams about literatures, for example, require students to study, to recall what they know, and to budget their time carefully as they write their answers. Particularly, the essay questions ask students to analyze and synthesize information and to arrange ideas in a series of clear, logically connected sentences and paragraphs. To illustrate:

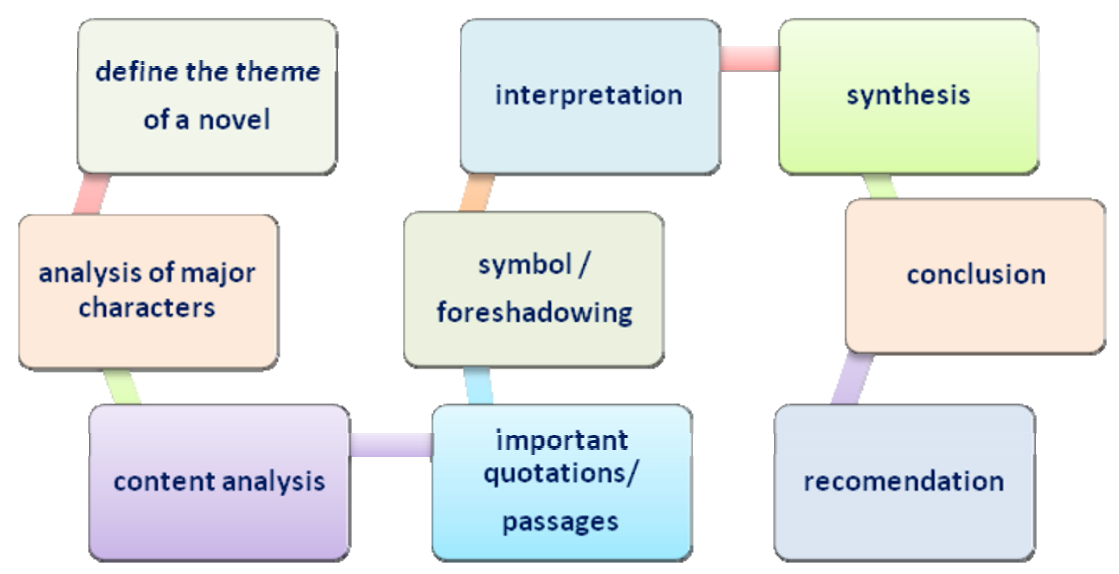

Therefore, the above writing skills process implies that students must do more than memorize the facts and must identify the relationships among them. In brief, under time limits of the essay exams, students must think critically, logically, and analytically about their subject: they must plan, shape, draft and revise an essay that clearly communicates their ideas to their audience (Writing essay exam about literature, 2012).

However, the IIS instructors found that many students were unable to meet the benchmarks of writing they set. The outcome from the first year program revealed that many students had difficulties in achieving the academic writing skills required, and some failed the course while some had a second thought and changed their program. The common problems of their writing incompetence laid in the fact that these students:

a) Especially, the non-native English speakers lacked writing practices as well as critical and analytical thinking skills.

b) Especially, Asians were unable to compose their thoughts and ideas clearly and logically.

c) Faced difficulties in expressing their viewpoints and did not provide adequate and appropriate facts to support their statements.

d) Did not learn the differences between the needs for responding to essay questions and the needs for objective tests; they prepared for all exams with the same learning strategies. 
Consequently, the IIS English faculty directed considerable effort towards the measurement of writing ability and frequently gave a number of written assessments and essay exams to English- major undergraduates. Moreover, professors would examine further the problems students might have in their writing process.

Whether writing tests (e.g., essay exam and writing prompt test) improve students' writing competence and knowledge in curriculum?

Richards and Renandya (2001), the authors of Methodology in Language Teaching, stated, "If we test directly the skills that we are interested in fostering, then practice for the test represents practice in those skills. If we want people to learn how to write compositions, we should get them to write compositions in the test" (p.54). Because the act of writing involves the production of a written piece, actual writing samples, or direct measures of writing, now are viewed as a more appropriate means for assessing writing performance because they more nearly approximate real discourse (Carlson, Bridgeman, Camp \& Waanders, 1985).

Similarly, the IIS instructors gave students the essay exams and writing prompt tests to enhance their writing ability. Beside the writing essay exams, students were frequently engaged in a range of different forms of the writing tasks to ensure that their writing assessment practices were robust. For instance, students had to produce responses to literature, research reports, summaries, narratives and persuasive essay. They were given ample opportunities to experience and practice the essay writing skills, especially the needs for responding to essay questions (both short and lengthy ones) before they had to demonstrate them on the exam.

For the essay test preparation, the IIS instructors usually reviewed the material they had covered and tried to choose topics that would require students to bring together the major themes of the course. They also fueled class discussion by provocative questions relevant to the essay exam questions that students were going to take. Thus, students were given the adequate guidelines and practices. In case some were confused on the issue, the lecturers would go over and repeat the points until they completely understood and were able to connect their ideas to the aspects of the instructors' lectures. The skills in writing of students were expected to meet the following benchmarks:

(a) Consistently write clearly and effectively.

(b) Writings suitable for a variety of purposes and audiences.

(c) Recognizing the structures of various forms and applying these characteristics to one's own writing.

(d) Presentation by using analytical, logical and critical thinking processes coupled with problem-solving strategies.

(e) Synthesizing and communicating with information.

As a matter of practice, in the second year program of the IIS English-major students, their writing skills improved a great deal and could be observed from a number of writing tests and written assignments. After having taken many written tests, some students remarkably achieved advanced skills in writing, and some, at least, achieved the following writing qualities:

i) The ability to write clearly, logically and efficiently. 
ii) The ability to write prolifically for a variety of purposes and audiences.

iii) Able to organize and develop paragraphs with good structures.

iv) Know how to analyze and solve problems and then back up their statements and viewpoints with appropriate evidences.

v) Able to synthesize and communicate with information gathered.

The positive result derived confirms that the IIS professors used the appropriate and correct instruments to improve students' writing competence, knowledge in curriculum, and comprehension of the study.

\section{Whether writing test gives a valid and reliable instrument of measurement?}

"A test is said to be valid if it measures accurately what it is intended to be measured." (Richards \& Renandya, 2001, p.25). "By reliability is meant the stability of test scores. A test cannot measure anything well unless it measures consistently" (Harris, 1969, p.14). Harris continues that all good tests possess three qualities: validity, reliability, and practicality. In the section of any test, two questions must always be considered:

(1) What precisely does the test measure?

(2) How well does the test measure?

The essay exams given to the IIS English-major students possess, at least, two qualities which are content validity and reliability. The most important characteristic of any test is its content validity, which means how well it samples the range of knowledge, skills, and abilities that students were supposed to acquire in the period covered by the exam (Writing and grading essay questions, 1990).

Regarding the reliability of an essay test, some critics pointed out that essay examinations cannot be scored reliably. Essay test often has relatively low reliability because grading criteria can be difficult to writ (University of North Carolina, 1990). However, English literature professors at the IIS revealed that essay exams can be scored reliably if they are carefully constructed, and if the scoring is completed by competent, well trained readers/scorers. The essay question which is as important as reader reliability is the reliability of students' performance.

Concerning practicality (usability or means of facility), some critics argued that it would be of minimal qualification to score students' essay examinations when the class is large in size, which requires much more time to grade. On the other hand, the instructors are of high standard and real expertise in that particular field would see them as not a problem. Harris (1969) states, "It is now clear that there are ways to administer and score composition tests so that they, too, may be used by themselves as reliable instruments." Therefore, the IIS instructors used the essay exam as a valid, reliable, and particle instrument to assess students' ability to create, analyze, synthesize, and evaluate.

\section{Strengths of Essay Exam}

One of the qualities of the essay test is that it allows students to think outside the box. Students have an opportunity to discuss and express their feelings and viewpoints as well as sharing their life experiences. This is related to what Jacobs (2010) describes the Strengths of Essay Items as followed: 
i) Essay items are an effective way to measure higher level cognitive objectives. They are unique in measuring students' ability to select content, organize and integrate it, and present it in logical prose.

ii) They are less time-consuming to construct.

iii) They have a good effect on students' learning. Students do not memorize facts but try to get a broad understanding of complex ideas to see relationships, etc.

iv) They present a more realistic task to the student. In real life, questions will not be presented in a multiple-choice format but will require students to organize and communicate their thoughts.

\section{The Field of Testing and Measurement}

Students were initially given the writing prompt tests under the time limits of 1 hour responding to the novel on the chapters and parts covered in class after the first four weeks of the course. Then they were engaged in the essay exams under the time limits of 2 and 3 hours accordingly for midterm and final. To illustrate samples of the writing prompt test and the essay exam questions:

Example I. In-Class Writing Prompt Test

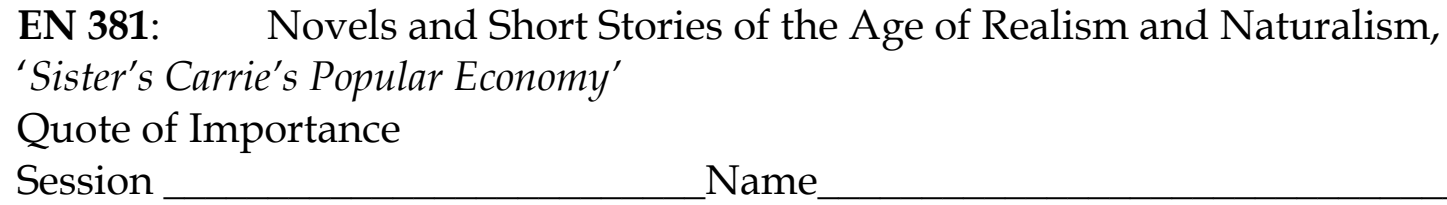

I. Copy your quote or sentences that stick out for you in assigned reading for today with page number.

II. Why does this quote have particular meaning for you?

III. Can you relate this quote or sentences to contemporary issues? Why?

Part of student's sample response to the test questions:

The novel Sister Carrie opens a discussion on one of the oldest professions in the world. Is it morally right for women to sell herself in order to secure positions or economic gains? Written by Theodore Dreiser in 1990, Caroline Meeber or Sister Carrie, an eighteen-year-old girl, boarded a train from Columbia City headed for Chicago where wage seekers converging during the economic boom after the Civil War $[\ldots]$.

I. Based on my assigned reading, the following quote is significant and needs to be analyzed regarding the situation of economic boom after the Civil War: "He reached down in his hip pocket and look out a fat purse. [...] In deed an experienced traveler, a brisk man of the world, had never come within such range before. [...] he did things, built up her dim world of fortune, of which he was center. It disposed her pleasantly toward all her might do" (p.8).

II. This quote has particular meaning for me because Carrie, an eighteen- yearold girl, is seeking fortune, money, and her self-interest. The man named Drouet she meets in this scene seems to have everything she is looking for. Therefore, readers 
can imagine that he is attractive to her right away [....].

Example II. In-Class Essay Exam

EN 464: William Shakespeare's Comedies, 'A Midsummer Night's Dream' In-Class Essay Exam \# II

Your Name

Write an essay in which you describe some of the aspects of love that Shakespeare includes in A Midsummer Night's Dream. In your way answer be sure to include details of the characters involved and the situations in which they find themselves.

Part of student's sample response to the essay question:

The main theme of "A Midsummer Night's Dream," written by Shakespeare revolves around love relationship and the comedy of errors. The plot of the play includes fantasy, magic, and dreams. The aspects of love that Shakespeare portrays in the play are, for example:

Reluctant love. Act1, scence1, p.45 is the conversation between Theseue, Duke of Athens, and Hippolyta, Queen of Amazons. Under the circumstances and contract of winning the war, Theseue is rightful to make Hippolyta marry him. Although she probably does not love him yet, he loves her in the play. The main point is that Theseue wins the war, therefore, he has absolute power over anyone and can do anything he wishes for [....] traits of a winner and ruler.

Comic love. The play of "Pyramus and Thisbe" is performed by tradesmen such as Bottom, Flute, Quince, Snout, Snug, and Robin in front of the wedding dinner of Theseus and Hippolyta and also the two pairs of the young couples. Because these Athenian tradesmen are not professional theatrical performers, their actions in "Pyramus and Thisbe" turn into comic love.

Example III. In-Class Essay Exam

EN 473: Earnest Hemingway, 'The Old Man and the Sea'

In-Class Essay Exam \# IV

Name Date

1. What do we learn of the old man's relationship with the boy, Santiago?

2. What does Hemingway want us to think about Santiago's state of mind as he speaks (a) to his hand (b) to the fish (c) to himself?

3. What are Santiago's feelings and reactions during his battles with the sharks?

4. What feelings does Hemingway leave us with the end of the story? 
Part of student's sample response to the essay question:

'The old man and the sea' written by Earnest Hemmingway won a Pulitzer Prize in 1953. The story portrays the life of the old Cuban fisherman, Santiago, and his remarkable experience of fishing a great marlin, said to be the largest catch of his life. The old man serves as a novel's protagonist [...]. At the end, even though only his marlin's carcass is left, Santiago is considered a winner because he never quits and strongly fights off the sharks until there is nothing left to fight for.

Through Santiago's eye, "There are many good fishermen and some great ones. But there is only you" (p. 23). The old man is his great teacher of fishing. The boy will make use of those lessons he has learned from his teacher after he dies. All the old man's noble qualities and lessons he draws from his experience will be passed on to the boy, which means the fisherman's life will continue on, in some form after his death.

The example of Santiago's state of mind as he speaks to his hands is illustrated on page 64 to 65 . "It will uncramp though...to help my right hand. There are three things that are brothers: the fish and my two hands" (p. 64). As Santiago speaks to his left hand which is cramped while his right one is bleeding during battling the big fish, he prays to Virgin Mary for bringing back strength to his physical hands that he can win this big game of fishing as his prize.

From the illustration above and step by step, the students majoring in English improved their academic writing skills after taking a number of the writing prompt tests especially the essay exams. They are the most effective of all types of exam suited for testing the levels of students' ability of academic writing which includes cognitive skills such as problem-solving, analysis, synthesis and communication with information gathered. It can be concluded that the essay exam and writing prompt test are justifiable to measure students' writing competence, knowledge in curriculum, skills, and ability because they are valid and reliable instruments of measurement.

\section{Whether writing tests yield the backwash effects on teaching and learning approaches at the IIS?}

Backwash can be broadly defined as the effect of a test on teaching and often also on learning (Apichatrojanakul, 2011, p.115). Gates (1995) mentioned that if backwash is strong, students and teachers will alter their classroom behaviors in order to achieve good marks in the test. Based on the findings of this study, the purposes and methods of testing on writing promoted both positive and negative backwash effects.

\section{Positive Backwash}

For English-major students, in their first year program, many of them experienced difficulties in writing an essay exam and the writing prompt test and thus they may earn low scores (C. Herman, personal interview on January 14, 2012). After having experienced the writing exams for the first entire year program, students gradually 
came to understand and realize what kind of skills they were frequently assessed, and what else they needed to do more in order to earn better or high scores. As a result, they changed their attitudes and formed a new approach toward the learning of their subjects. The acquiring of knowledge through memory becomes obsolete and of least importance to them. They emphasized more on the logical, analytical and critical thinking skills, and learned how to highlight the relationship between the major characters and situations in the novels, etc. There were some non-native English speaking students took intensive course for writing in order to attain higher level of writing skills and could pass the literature courses successfully.

For instructors, after some students, mostly the non-native English speaking students failed the writing exams, professors reevaluated and redefined the objectives of the courses they were teaching. Needs analysis for learners became more concerned for them. Some professors used essay questions as their teaching tools throughout the course instead of their previous teaching approach. This way made students to be familiar with the types of essay questions. As a consequence, they could understand what kind of answers the lecturers were looking for and be able to respond to essay questions effectively and properly. Furthermore, some literature instructors built a partnership with their students by sharing ideas, information, and questions which helped to develop their learning skills and performances on the exam. Some professors invited professional writers to work with students, thus, they were encouraged to find their best means to augment their writing assessments.

\section{Negative Backwash}

On the contrary, there are some negative backwash effects of writing tests. For example, students may try to cover up their weaknesses in the written tests by avoiding subjects they found difficult. Some students may even attempt to cheat on the tests. Some professors might possess personal biases, whether be they good or bad, toward some students. The students who failed in many tests feel the pressure and drop out of class while those who were stressed out have a second thought and change their program.

\section{Interviews of Lecturers}

The first professor whom I interviewed was Prof. Gareth Finch from England, UK. He has been teaching courses of Composition, Essay and Criticism Writing at IIS-RU for three years. He pointed out,

Some students may have sought out proof readers that covered basic holes in their writing and prevented the teacher from knowing their true ability. Often, you must give students adequate time to compose an essay and this means you are not always able to watch the students' progress and monitor whether the work is being done alone (this applies to take-home written assignments rather than formal exams).

My next interviewee was Prof. Orpheus Stephens from the United States. He shared his point of view,

Looking at it from another perspective, I would say that a writing test is perhaps the most valid of all types of testing because it tests for objective 
viewpoints the student needs to show the instructor. This is most important in literature courses. Students must learn how to show in writing that they understand the complex ideas that they read in the literature. Having a multiple choice test of true or false test for a literature course doesn't accurately test the students' understanding of the material.

Another professor that I interviewed was Dr. Gary Hogle from the United States. He said,

I always define the importance of vocabulary, and punctuation, as the misplacement of one comma can change the meaning of an English sentence. I also help students to express the proper usage of vocabulary, in the composition of the writing. I have always taught the students, while verbally, or written, always keep in mind the word, "KISS," (keep it short and simple). Writing will express their written abilities to compose the vocabulary, grammar, and punctuation into a broad level of the attempted mastery of the English language. The strong effects can show the efforts of both, the instructor and the student, had applied to their learning.

The last professor whom I had an interview with was Dr. Edward L. Robinson, also from USA. He taught American and English literature courses at IISRU for two years. He expressed,

(a) I wanted students to be able to apply or demonstrate that they could take literary concepts and stories apply them to contemporary social and political situations. More importantly, I wanted to ground my students in literary skills that help them be critical readers in future course. Thus, I wanted my students to have a roadmap for reading and understanding new academic material. I also believe that writing exams help students become competent writers through the practice of literary analysis.

(b) I believe that literature classes should not be about remote learning such as definitions. I want to develop students' confidence in providing answers that are not uniform but how they see the literature as informed by their cultural and social experiences. Thus writing exams usually measure, for me, a sense of the student ability to read critically what is in the text and organizing the information as it manifest in their ways of being and living in the real world. Literature still has a critical role in teaching the human side of our new global economic reality. More importantly, I believe that literature must be a leading reference for teaching moral and social ethics.

(c) I think that the strong points of the assignments and class discussions resided in the fact that for many students in this particular course came to class prepared and ready to discuss their assigned chapters. More importantly, I felt like a trust develop in the class so that students could speak freely but also negotiate the material from the novel Sister Carrie of their own terms. I believe that literature is not about right or wrong according to the professor, but how each student/individual finds meaning in the literary text. Thus, the writing component of the class served to give and promote a safe space for students to find their literary and writing voice.

The weak points of my instruction are the inability to work personally with each student. The language difference and barriers in the class provides some 
problems. This is why I worked to create students groups in hopes that the more advance students would serve as a helpful guide for students who were less advance. Especially in the Thai culture where asking professors question could be considered losing face."

\section{Interviews of Students}

David Gevuax is from England, UK and was an English-major student. He described,

I had never written a properly formatted essay before studying at IIS, so I was pleased with the content of some of the basic courses I studied there. The style of my writing did not change; however, I was not familiar with the proper formatting before studying at IIS. In addition, I worked for a large recruitment company, and the job applying candidates have to write a letter and also a creative piece of writing. Employers need to know the candidates English ability before they are given a job, this test is very important for the job candidates, to get good results in if they want to work in a decent organization.

The next interviewee was Crystal Hermann from Chicago. She mentioned,

The first semester that I took the written tests of some literature courses, I was so stressed out! It was very difficult for me to analyze the novel such as Victorian and Edwardian Literature. I took the course because of its syllabus that drew my attention. I did everything possible to optimize my potential marks, and then I must accept that the essay exam has yielded a great impact on my writing development. I think writing proficiency predicts a student's academic achievement. The essay test is a powerful tool to measure students' writing competence. For me, there are no other test formats can accurately measure students' writing ability, intelligence and performance like the essay test does.

Ana, a student exchange program from Germany, pointed out,

Sometimes I can see that a short essay exam can measure some things just as well as a longer one and take much less time to be assessed. Do you think writing essay exams for two or three hours are much more reliable than the 30 minute one? Why the three hours could not be measured in much shorter time like 30 minutes? Sometimes students are frustrated when the exam questions are redundant and the direction is unclear. This makes students confusing so they don't know what kind of answers should be given on the exam.

Another interviewee was an anonymous student. He mentioned,

Considering a student's writing test, it is a debatable topic among researchers, particularly the academics in this field - whether or not this test is an effective tool to evaluate the student's critical ability toward a subject of study. On one hand, the student might sound credible after the writing exam when he or she thoroughly elaborates his or her analytical thoughts over a testing issue. On the other hand, how can we really know that this student's writing performance arises from his or her real comprehensive knowledge of the subject of study? To illustrate, a student may not know much about making a 
noodle soup, but he or she knows how to describe how to cook the meal. Can we justify that this student's well-descriptive writing expressions about making the noodle soup are his or her real expertise of this kind of food?

Yim is a Thai student. She expressed, "I agree with the written test because it allows students to express their idea through logical thinking process which is important for analysis, decision making and understanding. I believe a right curriculum can shape not only the way of learning in the classroom but also will finally create a quality citizen with full consciousness and rational for the society."

Jing, from Thailand, pointed out,

The essay and composition tests are challenging the students' writing competence. First of all, the students need to understand their lesson clearly in order to answer properly. This will help them on the thinking process. Before they write anything on the paper, they have to think in sequences of what will come before or after. They're pushed to be more proactive! Secondly, such writing tests would allow their freedom of thinking within the scope, instead of limiting them only to the choices or the method we want them to follow. This would help them dare to ask questions or think out of the boxes. Thirdly, we can understand how good their languages are. The teacher can help improve their skill specifically. The cons of the writing as I can think of are the quality of the questions. If questions became poor or unclear, this wouldn't help students in term of creativity or thinking process.

Next student was Thana Netkaew. He illustrated,

The written test takes time of thinking process. I lost lots of time in the past. Now, I have learnt to be precise and get to the point of the questions. This helps me to cover up all questions when we have a limited time. To do so, I always read and practice my skills. The essay examination allows me to make an argument and express my point of view. It is the process of thinking that improves and develops my writing skill. I have realized that writing skill requires more practices rather than being talented, so when the examination date comes I got confident and the exam just flows!

The last interviewee I talked to was a Thai student named Thanaporn Panitchanok. She said,

I think my writing ability was improved through the in-class writing tests. By taking the written exam, I have acknowledged more vocabularies and gained a better understanding of many new contexts. It also helps me in terms of my writing skills and grammatical mistakes. The essay test has been a great help in preparing my English written skills before entering the business world. By having a test, we have to prepare and study for the test, it improves our ability. I think it's very helpful indeed.

\section{Conclusion}

From the above interviews, it can be concluded that the essay exams and the writing prompt tests improved English-major students' writing competence and knowledge in curriculum. Such instruments are valid and reliable. Furthermore, the IIS instructors' implementation of testing writing yields the positive backwash effect more than the negative ones. The final result from this research concluded that the 
positive backwash from writing exam influenced a number of students majoring in English to change their learning behaviors and approaches and tried to meet the criterion of the course with great efforts. Importantly, the pedagogical skills instructors used to impart the specialized knowledge and content of their subject areas are priority. As Brown and Glanser (2003) emphasized on their research that students need to be able to look with new eyes at the work they have undertaken and to understand the reasons by which writing assessments have been made. For instructors, they need to ensure that they make it clear to their students that they are not just assessing what is easy to assess. The choices that make concerning the writing assessments should be valid and reliable in that they assess what they teach and what their students learn. 


\section{References}

Brown, S., \& Glasner, A. (2003). Assessment matters in higher education. Buckingham: SRHE and Open University Press.

Carlson, B. S., Bridgeman, B., Camp, R., \& Waanders, J. (1985). Relationship of admission test scores to writing performance of native and non-native speakers of English. Retrieved from http://www.ets.org/Media/Research/pdf/RR-8521-Carlson.pdf

Gates, S. (1995). Exploiting washback from standardized test. JALT Applied Material Language Testing in Japan, 101-102.

Gupta, D., \& Woldemariam, S. G. (2011). The Influence of motivation and attitude on writing strategy use of undergraduates EFL students: Qualitative and quantitative perspectives. The Asian EFL Journal Quarterly, 13(2), 34-35. Retrieved from http:/ / www.asian-efl-journal.com

Harris, P. D. (1969). Testing English as a second language. New York: McGraw-Hill Book Company.

Jacob, C. L. (2010). How to write better tests: A handbook for improving test construction skills. Retrieved from http:/ / www.indiana.edu/ best/write_better_tests.shtml

Apichatrojanakul, P. (2011). The washback effects of the TOEIC examination on the teachers and students of a Thai business school. In R. J. Kirkpatrick (2011), English language teaching in Thailand and Myanmar (pp. 115-119). Bangkok, Thailand: Shinawatra International University Press.

Richards, C. J., \& Renandya, A. W. (2001). Methodology in language teaching. Cambridge: Cambridge University Press.

Writing essay exam about literature. (2012). Retrieved from http:/ / academic.cengage.com/resource_uploads/downloads/1413022812_59 430.pdf

Writing and grading essay questions. (1990). For Your Consideration, No. 7. Chapel Hill, NC: Center for Teaching and Learning, University of North Carolina at Chapel Hill. Retrieved from http://cfe.unc.edu/pdfs/FYC7.pdf 